\title{
Uncertain Certainty?: Making Sense of the European Court of Human Rights' Standard of Proof
}

\author{
Christine Bicknell*
}

\begin{abstract}
The European Court of Human Rights declares a single standard of proof ('SoP'): proof beyond reasonable doubt ('BRD'). Yet the accuracy of this claim and the threshold's appropriateness have both been challenged. This article uniquely considers and clarifies the Court's interpretation and application of its SoP. Demonstrating SoP is capable of both broad and narrow interpretations, it shows the Court interprets SoP only narrowly. This understanding confirms BRD as the applicable standard, whose use is then considered through detailed examination of the case law. The analysis shows that although the Court's conception and approach to BRD necessarily accommodate some doubt, violations are found with a consistently high level of certainty. There is however, a striking inconsistency in references made to the Rules of Court. Moreover, the Rules do not fully capture the Court's approach. Addressing this, as the article proposes, would strengthen both the consistency and legitimacy of relevant decisions.
\end{abstract}

\section{Keywords}

European Court of Human Rights - Standard of Proof - Burden of Proof - Beyond Reasonable Doubt - Uncooperative States

\section{$1 \quad$ Introduction}

The European Court of Human Rights ('the Court') ${ }^{1}$ follows its own declared standard of proof ('SoP'): violation of a Convention right must be proven 'beyond reasonable doubt' ('BRD'). ${ }^{2}$ Strikingly, BRD is an evidential standard alien to civil law systems from which almost all of the Court's judges are drawn. ${ }^{3}$ Moreover, the Court distinguishes BRD from its

\footnotetext{
* Lecturer in Law, University of Exeter: c.bicknell@exeter.ac.uk; Academic Fellow of the Honourable Society of the Inner Temple. My thanks to Steven Greer, Stephen Skinner and Andrea Lista for their comments on previous drafts; Rebecca Helm and Richard Edwards for helpful discussions; and James Bicknell for his patience.

${ }^{1}$ The European Convention of Human Rights is referred to interchangeably as the 'ECHR' and 'the Convention'.

2 The standard was first set in Ireland $v$ the United Kingdom Appl no 5310/71 Merits and Just Satisfaction (18 January 1978).

${ }^{3}$ S Greer, The European Convention on Human Rights: Achievements, Problems and Prospects (OUP 2006), 218-220. DOI 10.1017/CB09780511494963; U Erdal 'Burden and standard of proof in proceedings under the European Convention' (2001) European Law Review 68, 74; L Loucaides, Essays on the Developing Law of Human Rights (Martinus Nijhoff 1995), 160. More generally: M J Bond. 'The standard of proof in international commercial arbitration', (2011) 77(3) Arbitration 304-317; C Brower 'Evidence before International Tribunals: The Need for Some Standard Rules' (1994) 24(1) The International Lawyer 47-58; Redfern et al, 'The Standards and Burden of Proof in International Law' (1994) 10(3) Arbitration International 317-364. The civil law systems themselves have by no means a uniform approach, see: M Taruffo, 'Rethinking the Standards of Proof' (2003) 51(3) The American Journal of Comparative Law 659- 677. DOI: 10.2307/3649122.
} 
application in domestic criminal courts where (in common law countries) it is most familiar. In particular, at the ECHR level the standard does not have the same underlying purpose: ${ }^{4}$ instead of setting the threshold to establish the guilt or innocence of an individual it is the measure against which a breach of state responsibility under the Convention is found. ${ }^{5}$ It has therefore been noted that BRD applied by the Court is 'not interpreted as the same high degree of probability as in domestic and criminal trials' ${ }^{6}$ The Court's approach includes a willingness to take into account circumstantial evidence, make inferences, reverse the burden of proof, and use constructive knowledge in its evaluation, all of which creates room for some level of doubt.

The Court's SoP carries obvious importance, not least because it can determine the outcome of a case. ${ }^{7}$ A clear understanding of the Court's interpretation and approach to its SoP should thus be vital to human rights practitioners and scholars alike. Oddly however, the topic has received very little attention and the academic literature that does exist presents a confusing picture since it has been variously argued: differential standards are in fact used, of which BRD is just one ${ }^{8}$; that 'in practical terms' the standard has been 'abandoned' by the Court altogether'; and (in judicial dissent) that BRD has no place in the ECHR case law and should yield to a different standard. ${ }^{10}$

\footnotetext{
${ }^{4}$ This is acknowledged by the Court itself. See for example: Nachova and Others v Bulgaria [GC] Appl nos 43577/98 and 43579/98 Merits (6 July 2005); Creangă v Romania [GC] Appl no 29226/03 Merits (23 February 2012); El-Masri v the former Yugoslav Republic of Macedonia [GC] Appl no. 39630/09 Merits (13 December 2012). See also Napier v Scottish Ministers 20051 SC 307.

${ }^{5}$ P Leach, Taking a Case to the European Court of Human Rights ( ${ }^{\text {th }}$ edn, OUP, 2017), 202. DOI: 10.1017/9781780688008.032; and Ireland supra n 2.

${ }^{6}$ Leach $i b i d$. at 202.

${ }^{7}$ See below.

${ }^{8}$ In particular M Smith, 'The adjudicatory fact-finding tools of the European Court of Human Rights' (2009) European Human Rights Law Review 206, 211; M Ambrus, 'The European Court of Human Rights and Standards of Proof: An Evidentiary Approach towards the Margin of Appreciation' in L Gruszczynski and W Werner (eds), Deference in International Courts and Tribunals (OUP 2014), Chapter 13. DOI: 10.1093/acprof:oso/9780198716945.001.0001.

${ }^{9}$ Erdal, supra $\mathrm{n} 3$ at 85.

${ }^{10}$ Ibid. citing instances of judicial criticism.
} 
The present article addresses the gap in current understanding of the Court's SoP: taking as its key aim to clarify SoP as it is declared, interpreted and applied specifically by the Court. Unique from other analyses, the Court's SoP is necessarily approached herein as a self-contained, stand-alone concept, specific and subject only to the Court's interpretation and application. It is shown that whilst SoP is capable of both broad and narrow interpretations, the Court's interpretation of the term is narrow. Based on this narrow construction, the Court names BRD as the applicable evidential standard. Analysis of the Court's conception and approach to BRD shows allowance of a certain level of doubt for two key reasons: the Court does not always have full access to evidence of facts; and in certain circumstances in response to which the Court reverses the burden of proof, there is necessarily a structural accommodation of doubt within its approach. Nevertheless, detailed examination of the case law indicates that violations are found with a consistently high level of certainty. However, the case law also highlights inconsistent reference made to the Rules of Court, which themselves offer an incomplete reflection of the Court's approach to proof when faced with an uncooperative respondent state. Both may have implications for the strength, efficiency and legitimacy of decisions, and a way forwards is proposed.

In what follows, Section 2 clarifies key terms. Section 3 indicates three specific tensions obscuring present understanding of the Court's SoP: divergent interpretations of SoP; divergent interpretations of BRD; and concern that BRD is too high a standard. Section 4 examines the first tension, demonstrating the Court conceives the term 'SoP' only narrowly, and on which basis declares its standard is BRD. Sections 5-7 then examine the Court's interpretation, approach and application of BRD. Section 5 outlines the Court's specific approach to establishing proof BRD, and some contextual detail explaining the need for it. Section 6 elaborates, discussing the origins of the Court's use of BRD and the development of its general approach. It also highlights inconsistency regarding the Court's 
reference to its Rules of Court, arguing this should be addressed. Section 7 examines the application of the Court's approach in the case law, having particular regard to the Court's rigour and the certainty of its findings that result. Section 8 concludes.

\section{$2 \quad$ Clarifying the Terms}

Three key terms are frequently referred to in this discussion: standard of proof (SoP), burden of proof ('BoP'), and beyond reasonable doubt (BRD). It is noted already that the Court's declared SoP is BRD. Though the two are related, they are nevertheless separate labels and are treated as such in the discussion. For present purposes it suffices to regard BRD as a subset of SoP, recognising that within legal systems it is just one standard available among others. ${ }^{11}$ However, SoP is also closely related to, but distinct from, BoP and it is relevant at this point to clarify these terms and their relationship with one another.

In essence, BoP places the onus on one party to do the proving, whilst SoP can be explained as the 'degree of satisfaction' to which the court or tribunal must be persuaded of that proof. ${ }^{12}$ It 'fixes the necessary and sufficient degree of belief or confidence the factfinder, upon evaluation of the evidence, must have in the truth of [a disputed proposition]. ${ }^{13}$ To demonstrate the connection between the concepts evidence textbooks on the law of England and Wales ${ }^{14}$ commonly cite Lord Hoffmann's explanation of BoP:

If a legal rule requires a fact to be proved (a 'fact in issue') a judge or jury must decide whether or not it happened. There is no room for finding that it might have happened. The law operates a binary system in which the only values are zero and one. The fact either happened or it did not. If the tribunal is in doubt, the doubt is

\footnotetext{
${ }^{11}$ Eg. In civil cases Bond supra $\mathrm{n} 3$ identifies: balance of probabilities; clear and convincing; beyond reasonable doubt; intime conviction, and free assessment. Also Taruffo supra n 3.

${ }^{12}$ R Glover, Murphy on Evidence, (15 ${ }^{\text {th }}$ edn, OUP 2017), 89. DOI: 10.1093/he/9780198788737.001.0001.

${ }^{13}$ HL Ho, A Philosophy of Evidence Law (OUP 2008), 178. DOI:10.1093/acprof:oso/9780199228300.001.0001

14 The single common law country in the Council of Europe.
} 
resolved by a rule that one party or the other carries the burden of proof. If the party who bears the burden of proof fails to discharge it, a value of zero is returned and the fact is treated as not having happened. If he does discharge it a value of one is returned and the fact is treated as having happened. ${ }^{15}$

SoP accounts for exactly how persuaded a judge or jury must be to 'discharge' the BoP and return a value of one in the above scenario. According to Laudan the rationality and not just the strength of a court's confidence in the fact is 'crucial' ${ }^{16}$ It is beyond the scope of the present article to discuss this rationality in detail. But it is noteworthy that historically, the Court's approach to evidence had been arguably illogical, possibly irrational, and certainly counter-productive. ${ }^{17}$ The inequity of the outcome in Kurt $v$ Turkey, ${ }^{18}$ discussed in Section 6, when read against the wider context at the time, has subsequently informed the Court's willingness in certain situations, to make inferences and reverse the burden of proof: an approach that in the circumstances, can be regarded as more rational than previously. Indeed, it is demonstrated in the discussion below that at the risk of the charge BRD is not the Court's SoP at all, ${ }^{19}$ reversing the BoP actually operates as something of a leveller, bringing greater parity between parties in the dispute. Kokott notes this reflexive approach in international tribunals, and suggests that though they do not always distinguish the 'degree of persuasion' required by the BoP from its allocation, both reflect 'a balancing between the

\footnotetext{
${ }^{15}$ Lord Hoffmann in Re B (Children) (Care Proceedings: Standard of Proof) CAFCASS Intervening [2009] 1 AC 11, [2].

${ }^{16}$ L Laudan, 'Is Reasonable Doubt Reasonable?' (2003) 9 Legal Theory 295, 304-5. Also Ho supra n 13, 178185. DOI: $10.1017 / \mathrm{S} 1352325203000132$.

${ }^{17}$ GS Sethi, 'The European Court of Human Rights' Jurisprudence on Issues of Forced Disappearances' (2001) 8 Human Rights Brief 29; A Reidy, F Hampson and K Boyle, 'Gross Violations of Human Rights: Invoking the European Convention on Human Rights in the Case of Turkey' (1997) 15(2) Netherlands Quarterly of Human Rights 161-174.

${ }^{18}$ Kurt v Turkey Appl no 24276/94 Merits and Just Satisfaction (25 May 1998).

${ }^{19}$ Erdal supra $\mathrm{n}$ 3. Also H Keller and C Heri, 'Enforced Disappearance and the European Court of Human Rights: A 'Wall of Silence', Fact-Finding difficulties and States as 'Subversive Objectors' (2014) 12 Journal of International Criminal Justice 735, 739. DOI: 10.1093/JICJ/MQU042.
} 
particular individual right as compared with the state interest. ${ }^{, 20}$ She also observes that 'external circumstances' such as 'the time, manner and place of an occurrence influence the allocation of the burden of proof., ${ }^{21}$ With this in mind, let us turn our attention to the article's core task: examining the Court's approach to SoP.

\section{$3 \quad$ Three Tensions}

Three inherent tensions surrounding the Court's SoP presently obscure our full understanding of it. In this Section they are outlined, and are subsequently examined through the rest of the work as a means of more fully making sense of the Court's SoP. Briefly stated, the tensions are rooted in: 1 . academic commentary declaring the Court has differential SoPs against the Court's view it has just one, BRD; 2. difference in interpretation of BRD between domestic Courts, commentators, and the Court, which informs criticism the Court does not meet the BRD standard, and 3. concern at the appropriateness of BRD as the Court's chosen SoP, being such a very high standard, yet applied to prove the most serious of human rights abuses. The first two tensions are variants of essentially the same problem: descriptive accounts of what the SoP is, and how it is to be evaluated, are approached in markedly different ways depending on varying points of reference. In particular, this is whether the respective concepts are viewed self-referentially by the Court, or more broadly in academic commentary which invariably brings additional preconceptions to the analysis. The third tension relates to a normative difficulty far beyond the scope of this article to resolve.

However, highlighting the problem and related issues within it can improve understanding and to a certain degree explain the Court's declared approach and its implementation. It is for this purpose only the third tension is engaged in this work.

\footnotetext{
${ }^{20} \mathrm{~J}$ Kokott, The Burden of Proof in Comparative International Human Rights Law: Civil and Common Law Approaches with Special Reference to American and German Legal Systems (Kluwer 1998), 136.

${ }^{21}$ Ibid.
} 
Regarding the first tension between claims in the literature there are multiple or differential standards of proof in the ECHR system whereas the Court insists it has just one, $\mathrm{BRD}$, neither assertion is actually incorrect. The fact they stand apparently at odds is a consequence of difference in framing. The term 'SoP' is not understood or used in quite the same way between the Court and commentators, the latter tending to conceive it much more widely as encompassing, for example, margin of appreciation cases. This point is developed in Section 4, but in essence SoP is capable of both broad and narrow meanings, of which the Court applies the narrower. Broadly conceived, SoP encapsulates two distinct ideas: SoP in a very pure form, which relates to evidence of (proving) fact; and a standard which, because no fact is in dispute, is more akin to persuasion (of an argument or position) than strictly to proof. $^{22}$ The Court, where it declares BRD to be its standard, is referring to the first, and once this case is made out, this article confines itself thereafter to examining SoP in the narrower sense. Though there is merit in examining the Court's approach within the wider meaning of $\mathrm{SoP}^{23}$ doing so is beyond the scope of this article whose concern is to develop understanding of the Court's approach to SoP. The narrower focus on BRD aligns more fully with this purpose and also makes possible a more detailed examination of BRD than space would otherwise allow.

The second tension is a perceived difference of view as to the level and quality of evidence needed to satisfy BRD. There is very little literature on the Court's approach. Nevertheless its use of circumstantial evidence, - for example, presuming death without confirmation death has occurred, - causes Erdal to declare the standard has been abandoned. ${ }^{24}$ Where there is difficulty ascertaining the full facts, such as what happened to a person last seen in state custody but whose whereabouts are now unknown, the Court may make

\footnotetext{
${ }^{22}$ See section 4.

${ }^{23}$ Greer, supra $\mathrm{n} 3$ at 211.

${ }^{24}$ Erdal, supra n 3 at 68 . Also Judge Matscher in his partly dissenting judgment in Kurt, supra n 18, on which see Smith, supra $\mathrm{n} 8$ at 222.
} 
inferences and reverse the BoP, reverting it to the state. This is discussed in detail below but has been a source of contention. The Court's more recent references to 'constructive knowledge', - a very particular kind of inference, - presents an additional challenge to the perceived strength of BRD as interpreted and applied by the Court. ${ }^{25}$

At face value these interpretative techniques could be regarded as an error in labelling for argument that in spite of its claims to the contrary, the Court applies a standard that is not BRD. However, to comprehend the Court's interpretation, this article adopts a slightly different approach to other critiques, taking as its start point that there are 'different conceptions of the same concept' (BRD), applied and/or expected between domestic courts, external commentators, and the Court. ${ }^{26}$ In this way, the content is engaged with the aim of determining the Court's conception of BRD, which is necessarily approached as a selfcontained, stand-alone concept; especially appropriate given the firmness and consistency of the Court's assertions BRD is its SoP. Though comparison with others' conceptions is still possible, this article's approach removes the risk of transposing external conceptions onto the Court as a basis of criticism. The core undertaking here is to understand, not to condemn, and furthermore, transposition would require subjective choice of a 'better' or 'ideal' conception and thereby risk being methodologically unsound.

BRD is not subject to interpretation common between the Court and domestic courts, ${ }^{27}$ but neither is there agreement between or even within relevant domestic jurisdictions as to its correct interpretation. ${ }^{28}$ Although we can approach BRD as (arguably) a

\footnotetext{
${ }^{25}$ Al Nashiri v Poland Appl no 28761/11 Merits and Just Satisfaction (24 July 2014); Husayn (Abu Zubaydah) v Poland Appl no 7511/13 Merits and Just Satisfaction (24 July 2014). See discussion in section 7.

${ }^{26}$ Borrowed from George Lestas' evaluation of divergent interpretations of autonomous concepts under the ECHR. G Lestas A Theory of Interpretation of the European Convention on Human Rights (OUP 2007), 52. DOI: 10.1093/acprof:oso/9780199203437.001.0001.

${ }^{27}$ Supra $\mathrm{n} 4$ and Leach, supra $\mathrm{n} 5$.

${ }^{28}$ For particularly good discussion, Z Long, "Beyond Reasonable Doubt" in the Chinese Legal Context' (2014) Peking University Law Journal 339-371. DOI: 10.1080/20517483.2014.11424475.
} 
measure of certainty, ${ }^{29}$ or of truth, ${ }^{30}$ there is no clear agreement on its definition ${ }^{31}$ which, taking into account it is most often applied by untrained juries in common law countries, makes variance of interpretation and application of BRD to a set of facts inevitable. At its historical origins in English criminal law BRD developed to accommodate circumstantial evidence, ${ }^{32}$ and there is argument in the modern literature that the standard does and should carry a degree of flexibility. ${ }^{33}$ Even if broadly accepted BRD is a measure, albeit a very high measure, of certainty, conceptions of it are by no means constant. Accordingly, though it helps our understanding of the Court to observe the tension exists and is capable of obscuring understanding of the Court's application of BRD, it does not serve this article's purpose to make difference between the Court and other courts, domestic or international, the core focus. The purpose here is to explore SoP at the ECHR level, which - once the first tension is resolved, - means specifically, the Court's understanding of BRD. Hence it is equally beyond the scope of this article to make a comprehensive account of domestic approaches to BRD. Instead, engaging the second tension, the work closely examines the Court's jurisprudence to elucidate its particular approach in direct answer to the key question: how does the Court interpret and apply BRD?

\footnotetext{
29 Ibid.

${ }^{30}$ ML Friedland, "Searching for Truth in the Criminal Justice System" (2014) 60 Criminal Law Quarterly, 487521.

31 K Muller-Johnson, MK Dharmi, and S Lundrigan, 'Effects of judicial instructions and juror characteristics on interpretations of beyond reasonable doubt' (2018) 24(2) Psychology, Crime and Law 117 - 133. DOI: 10.1080/1068316x.2017.1394461; B Davidson and R Pargetter, 'Guilt Beyond Reasonable Doubt' (1987) 65(2) Australasian Journal of Philosophy 182-187. There have been attempts and arguments to quantify the value also, for example a cluster of related articles: J Franklin, 'Case Comment - United States v. Copeland, 369 F. Supp. 2d 275 (E.D.N.Y. 2005): Quantification of the Proof beyond Reasonable Doubt Standard' (2006) 5 Law, Probability and Risk 159-165. DOI: 10.1093/lpr/mgl017; P Tillers and J Gottfried, 'Case Comment - United States v. Copeland, 369 F. Supp. 2d 275 (E.D.N.Y. 2005): A Collateral Attack on the Legal Maxim That Proof beyond a Reasonable Doubt is Unquantifiable' (2006) 5 Law, Probability and Risk 135-157. DOI:

10.1093/LPR/MGL015; JB Weinstein and I Dewsbury, 'Comment on the Meaning of Proof beyond a Reasonable Doubt' (2006) 5 Law, Probability and Risk 167-173. DOI: 10.1093/LPR/MGL016.

32 Shapiro, "Beyond Reasonable Doubt" and "Probable Cause": Historical Perspectives on the AngloAmerican Law of Evidence (1991).

${ }^{33}$ See for example: E Stoffelmayr and S Seidman Diamond, 'The Conflict between Precision and Flexibility in Explaining "Beyond Reasonable Doubt"' (2000) 6(3) Psychology, Public Policy and Law 769-787. DOI: 10.1037/1076-8971.6.3.769.
} 
The third tension surrounds the appropriateness of BRD as the Court's SoP. It is beyond the scope of this article to consider this in detail. But it does serve our understanding to highlight the issue briefly here, and elements of this tension do inevitably arise in the discussion below. The origin of disquiet is that cases in which BRD is the applied standard are almost exclusively cases that involve disappearance, loss of life and/or torture. These are all matters that Greer, for instance, suggests require a strong 'priority to rights' in the Court's approach, much stronger than needed for Articles 8-11 for example. ${ }^{34}$ BRD seems a remarkably high threshold, especially in cases when the state attempts to undermine judicial process. Although this article does not build on the wider interpretation of SoP identified in the first tension, it is notable that commentary which has approached SoP in this broader way considers Articles 8-11 to attach a much lower evidential threshold. ${ }^{35}$ This certainly makes BRD where it is applied, seem odd, arguably even inexplicable, especially when the Court's purpose, to protect individual's rights against the state, is factored in. ${ }^{36}$

A difficulty facing the Court is that it must be alive to its position as an international court and any challenges to its legitimacy, actual or potential, ${ }^{37}$ that inevitably arise. BRD is broadly consistent with the evidential standard elsewhere in international law. ${ }^{38}$ Where the findings against a state 'imply a negative ethical judgment' upon it, the tendency is towards this higher threshold. ${ }^{39}$ It is arguably a strong safeguard against challenges to the legitimacy

\footnotetext{
${ }^{34}$ Greer, supra $\mathrm{n} 3$ at chapter 4.

${ }^{35}$ See section 4 below.

${ }^{36}$ The Court's purpose has been explained in numerous ways. This statement is not intended as in any way definitive.

${ }^{37}$ See K Dzehtsiarou, European Consensus and the Legitimacy of the European Court of Human Rights (CUP 2015). DOI: 10.1017/CBO9781139644471.

${ }^{38}$ R Wolfrum and M Möldner, 'International Courts and Tribunals - Evidence' [2013] Max Planck Encyclopedia of Public International Law <http://opil.ouplaw.com/view/10.1093/law:epil/9780199231690/law9780199231690-e26 > accessed 19 September 2018. Note, there are parallels between the approach in Corfu Channel, United Kingdom v Albania ICGJ 199 (ICJ 1949) and that of the ECtHR in the way it expresses its approach to evidence. See G Dobry, 'The Use of Circumstantial Evidence to Establish International Responsibility' (1958) 44 Transactions of the Grotius Society 63.

39 Ibid.
} 
of judgments, and furthermore, it is a means of providing as far as possible an account of truth which is often desperately sought by family members if not the victims themselves.

\section{$4 \quad$ Standard of Proof: the Subject of Differential Interpretations}

Let us address, and eliminate from further discussion, the first tension: the disjoin between the Court's insistence it has a single SoP against a view in the, admittedly sparse literature relating to the Court directly, that it applies different standards. The content of judgments informing this perception varies, but the overall finding can be summarized that the standard applied by the Court depends on the type of case before it. This is true within many domestic legal systems where it is relatively uncontroversial. ${ }^{40}$ The key difference is the Court's claim it has just one SoP. There are two distinct bases in the Court's jurisprudence on which the view of multiple SoPs has been suggested: where margin of appreciation cases are discussed in relation to SoP; and where the future-looking nature of non-refoulement cases is compared with cases that seek violation findings for past events. The key issue in the first tension is hence the scope of content to which SoP is used directly as a label.

Where the Court's SoP is discussed with reference to margin of appreciation cases, it is clear the term SoP is more broadly applied by commentators than it is by the Court itself. ${ }^{41}$ Ambrus' detailed critique of the Court's SoP is a good example. Although Ambrus does not raise any direct challenge to the Court's position (that it has a single SoP), her interpretation stands at very clear odds with it since she indicates multiple SoPs. ${ }^{42}$ In that analysis however, the type and range of cases she considers is much broader than those in which the Court declares its standard. If we can assume, as seems reasonable, the presence or absence of a declared SoP in a decision identifies cases in which the Court considers it relevant, this starts

\footnotetext{
${ }^{40}$ Note possible exceptions: M Schweizer, 'The civil standard of proof - what is it, actually?' (2016) 20(3) The International Journal of Evidence \& Proof 217-234. DOI: 10.1177/1365712716645227.

${ }^{41}$ Examples: Ambrus (n 8), Greer (n 3) and Smith (n 8).

${ }^{42}$ Ibid.
} 
to explain the variance. Cases indicated by the Court are examined in the Sections below, but it has already been observed these are generally cases involving disappearance, loss of life and torture claims. Ambrus' work covers the full range of ECHR rights and decisions, drawing links between the subject matter before the Court and the way it approaches evidence, including its use of language. As she explains it: under Article 2 and 3 applications, the Court refers to SoP, whereas in Articles 8-11 and Article 14 applications it refers respectively to 'margin of appreciation' and 'level of scrutiny'. For the Article 2 and 3 case law 'the main issue is often to prove whether or not certain facts are true or an event occurred. ${ }^{43}$ In margin of appreciation cases by contrast ' $[\mathrm{t}]$ he question posed by the Court ... [is]: to what extent should the Court be convinced that the State was entitled to interfere with the right at stake?"44 This assessment is correct. But by their content and the issue the Court is called on to determine, these are markedly different points: different content requiring 'proof' and different ways of 'proving' between actually demonstrating the truth of fact, or alternatively, without any need to prove fact, persuading the Court that position $\chi$ is to be preferred to position $\gamma$. Greer regards the Court's interpretative work similarly where he sees the Court's task in margin of appreciation cases is determining the scope of the right(s) at issue. ${ }^{45}$ On Ambrus' evaluation '[t]he degree of ... conviction varies, usually described in terms of the different margins of appreciation, which can be translated as different standards of proof placed on the respondent. ${ }^{46}$

Where does this leave us? And what does it tell us about the Court's interpretation of SoP? It seems clear that the disjoin between Ambrus' analysis and the Court's single declared SoP hinges on semantics of what proof is considered to entail: a point which relates to both

\footnotetext{
${ }^{43}$ Ambrus, supra $\mathrm{n} 8$ at 238.

${ }^{44}$ Ibid 240.

${ }^{45}$ Greer, supra $\mathrm{n} 3$ at chapter 4.

${ }^{46}$ Ambrus, supra n 8 at 240.
} 
the content of what must be proven, and how (with what evidence, or what argument) it is proven. Critically, there are two distinct kinds of ECHR cases; 1. those which require the discovery of facts to establish a factual situation in which a violation occurred; and 2. those involving a weighing up of competing considerations through such principles as proportionality of the margin of appreciation, leading to a judgment that a given right has, or has not been violated in the circumstances. In very simple terms, the division is between proof of facts and proof of a different quality, of a more persuasive kind, that a given position is correct. The first type is, or at least should be, the more objective of the two and calls to mind Lord Hoffmann's words, because this also is binary: a fact or factual set of circumstances is either true or it is not. Conversely, with her focus on margin of appreciation Ambrus is arguably more concerned with standard of review, which 'generally refers to the degree of deference that a court grants to institutional decisions taken by other authorities. ${ }^{47}$ That application of SoP as a label is not wrong, it is simply different. SoP is capable of a wide interpretation that includes both kinds of case, facts or persuasion, and it is also capable of a narrower handling, concerned only with proof of fact or, more specifically, of a Convention violation. Without any exception, the cases in which the Court has expressly declared its SoP are the first type of case, requiring proof of facts.

Non-refoulement cases have also yielded a finding that the Court has more than one $\mathrm{SoP}^{48}$ and we must consider their fit within this fact / persuasion dichotomy. Consistent with the findings above Smith writes 'there is no formalized standard or burden of proof in the Strasbourg case law', and that SoP 'depends to a certain degree on the issue raised under the Convention. ${ }^{49}$ But Smith introduces the relevance of time to this indicating that BRD is

\footnotetext{
${ }^{47}$ Ragni, 'Standard of Review and the Margin of Appreciation before the International Court of Justice' in Gruszczynski and Werner (eds), supra $\mathrm{n} 8$.

${ }^{48}$ Smith, supra $\mathrm{n} 8$.

${ }^{49}$ Ibid at 210 citing Rogge, 'Fact-Finding' in RStJ Macdonald et al. (eds), The European System for the Protection of Human Rights (1993) 677 at 678.
} 
applied to 'backward-looking inquiries' which consider whether a right has (ie. in the past) been violated. ${ }^{50}$ Cases relating to removal or deportation are future-looking and the Court instead requires 'substantial grounds' that there is a 'real risk' of violation. This is a much lower threshold to meet and Smith correctly identifies it as an SoP. In such cases the Court is silent however, and does not formally declare or label this an SoP. We could ask how and why this should be, but in practical terms, labelling would add nothing. The Court's requirement for this type of application is visible in its decisions.

The question remains: why would the Court still insist it has a single SoP, BRD? That insistence almost certainly relates to points noted above regarding the third tension in Section 3 surrounding the Court's position as an international court, legitimacy concerns and the nature of the rights and case law involved where that standard is declared. But the silence in this context may equally be informed by the wide/narrow conceptions of SoP within which, it is perfectly plausible, the Court does not regard 'real risk' to fall. Of the two types of case, requiring proof of facts or persuasion of a position, 'real risk' evaluation must fall within the second category because the Court must look at the possibility of what could occur rather than factual evidence of what has. Quite obviously a thing that has not yet happened cannot become proven fact. This being so, the silence over SoP seems to confirm the argument: the Court (formally) interprets SoP in a narrow sense as referring to factual proof a violation has occurred. The Court's approach to SoP being the interest of this article, examining its use of this narrower interpretation is the focus through the remainder of the work.

\section{The Court and "Beyond Reasonable Doubt": the Problem in Sketch}

The Court, as we know, declares a single SoP: proof beyond reasonable doubt. But while it has been shown the Court interprets SoP differently from some of the external commentary,

\footnotetext{
${ }^{50}$ Smith, supra $\mathrm{n} 8$ at 210.
} 
its approach to the standard even when narrowly defined does not easily leave the sense that BRD is or can be satisfied in every case. That is the crux of this discussion's second tension, and resolving it appears at first glance to raise three key questions: how does the Court interpret the BRD standard? How does the Court apply the BRD standard? And does the Court, in its jurisprudence, satisfy BRD on every occasion?

The first two questions are closely linked and difficult to pull apart since the Court's application of BRD should be indicative of its interpretation. Nevertheless, so far as possible, the approach below covers interpretation first, before fleshing in more detail on its application in the case law. The resulting evaluation is built directly on observation of the jurisprudence: the point of reference is the ECHR system itself. The third question however, is not the right question for this discussion. Asking whether the Court satisfies BRD every time requires a value judgment because, much like the first tension, it hinges on interpretation of what BRD is and how it can be satisfied. As observed in Section 3, there is no full agreement within domestic jurisdictions on this point. It follows that unless we are willing to impose an external interpretation on the Court as the correct one, once the first question has been discovered, so long as the Court is always true to its own interpretation of BRD, the answer to whether the Court really satisfies that must logically always be 'yes'. To avoid arguing in circles, we can therefore be alive to the fact there are different conceptions of this key concept without the need to select or favour any particular conception of our own, and continue the approach of unpacking the Court's interpretation of its SoP as a stand-alone concept. It is much more relevant to developing an understanding of SoP in the Convention system to concentrate attention to identifying and examining the Court's own conception of BRD. As a start point, without becoming bound up in external conceptions, it is helpful to highlight some of the concerns over the Court's use of BRD. In this way a general sketch of the Court's approach is necessary here, and some contextual reasons for its adapted or 
'nuanced' 51 approach to BRD are explained. Section 6 elaborates on this to discuss the origins of the Court's use of BRD, and the development of its general approach.

Suggestion that the Court has a nuanced approach to BRD begins with its own explanation. The Court standardly acknowledges that its SoP does not have the same underlying purpose as that adopted in criminal courts at the domestic level. ${ }^{52}$ From its first formulation of that standard put forward in Ireland $v$ United Kingdom and repeated ever since, its willingness to draw inferences has been visible:

According to its [the Court's] established case-law, proof may follow from the coexistence of sufficiently strong, clear and concordant inferences or of similar unrebutted presumptions of fact. ${ }^{53}$

Furthermore, the ability to make presumptions when a state is not cooperating in the judicial process is now codified in the Rules of $\mathrm{Court}^{54}$ and is part of the fabric of its approach. Uncooperative states are indeed the main source of the problem, and it should be noted that establishing facts has presented an issue in only comparatively few cases. The exhaustion of domestic remedies requirement under Article $35 \S 1$ ECHR to bring a case to Strasbourg, and the subsidiary nature of the Court, means that in the vast majority of cases the facts have already long since been established. ${ }^{55}$ This no doubt accounts for the relative lack of academic literature about the standard. Nevertheless, the facts are not always fully settled, and this occurs primarily when a respondent state is not being fully cooperative in the process, usually by withholding or failing to provide vital information to the Court. The Court on these occasions finds itself in a position at least approximating that of a court of first

\footnotetext{
${ }^{51}$ Keller and Heri, supra n 19 at 739.

52 Supra $\mathrm{n} 4$.

${ }^{53}$ Ireland (n 2), para 161. Repeated verbatim since, for example: Kasymakhunov v Russia Appl no

29604/12 Merits and Just Satisfaction (14 November 2013), para 100.

${ }^{54}$ Rule 44C $\$ 1$ discussed below.

${ }^{55}$ Erdal, supra n 3 at 71.
} 
instance, ${ }^{56}$ and though 'sensitive[ity] to the subsidiary nature of its role' makes it 'cautious' to approach it in this way, circumstances sometimes make it 'unavoidable'.${ }^{57}$ Greater consideration may be given then to circumstantial evidence, with the general approach of making inferences and reversing the BoP such that the State must disprove the disputed facts. Here begins the criticism, not that the Court's approach is incorrect, but that its standard is not strictly BRD.

Erdal's concern over death being 'discovered' without real proof of death was noted above. In addition, Keller and Heri observe that in disappearance cases the Court makes a 'departure' from the BRD standard. ${ }^{58}$ It is typical of this type of case that the State is not a cooperative partner, and instead a 'subversive objector', for example, withholding facts from the Court known only to it. As they point out, state denial is a defining aspect of disappearances and 'redistribution of the burden of proof' comes as a result not only of the severity of the allegations and the rights in question, but also because of 'lack of clarity about the factual situation'. ${ }^{59}$ Hence, they are not critical of the approach, only observe that it does not fit with (their conception of) BRD as a standard.

To make sense of the Court's approach, context is key. This includes that the Court is an international court ${ }^{60}$ and that there is a power imbalance between the parties. According to Wolfrum and Möldner, international criminal and human rights proceedings have a rough equivalence with domestic criminal proceedings in which the state holds a dominant position. Because of this they argue that in both types of case 'other considerations may have to be taken into account' ${ }^{61}$ While obviously inter-state claims can be brought to the Court, of

\footnotetext{
${ }^{56}$ Ibid.; Keller and Heri (n 19), 738. Also El-Masri, supra n 3, para 151.

${ }^{57}$ Al Nashiri v Poland (n 25), para 393. See also: Imakayeva v Russia Appl no 7615/02 Merits and Just Satisfaction (9 November 2006) para 113; Aslakhanova and Others v Russia Appl nos 2944/06, 8300/07, 50184/07, 332/08 and 42509/10 Merits and Just Satisfaction (18 December 2012) para 96; and El-Masri (n 3) para 154.

${ }^{58}$ Keller and Heri, supra $\mathrm{n} 19$ at 739.

${ }^{59}$ Ibid. at 738.

${ }^{60}$ Dzehtsiarou, supra n 37.

${ }^{61}$ Wolfrum and Möldner, supra $\mathrm{n} 38$ at para 5.
} 
which Ireland itself serves as an example, the respondent state may still control important information and be regarded as dominant in this way. A feature of that dominance is the control the State has over documentation and other evidence useful to the Court. The practical implications of this when BRD is the standard mean that without appropriate adjustment it would be straightforward for a state subvert process by withholding evidence to which it has exclusive access. This precise point was made by the Irish government in Ireland and has happened on numerous occasions with varying success for governments. The power differential can, and has been exploited to states' advantage.

Although in the domestic courts, the El-Masri litigation in the United States ${ }^{62}$ illustrates the point well. This was a rendition case brought in the United States in which the executive successfully relied on its stronger position to invoke the 'state secrets privilege' and withhold relevant information. By consequence, when the courts upheld the privilege, the claim failed altogether, with no recourse to justice for the victim of kidnapping, false imprisonment, incommunicado detention, and torture. ${ }^{63}$

In Europe lack of necessary information from the state defeated the disappearance claim in Kurt v Turkey, ${ }^{64}$ more on which below. Normatively, the case for adjusting the approach to evidence is clear and, as we know, (and since Kurt) the Court will now make inferences and reverse the BoP. However, this again raises the equally valid question over whether the standard of proof should be BRD at all (ie. the third tension). For the present it can be noted the justification for the high evidential standard is not abundantly clear, and has never been set out by the Court.

\footnotetext{
${ }^{62}$ El-Masri v Tenet 437 F.Supp. 2d (E.D.Va. 2006); El-Masri v United States 479 F. 3d (4 Cir. 2007). For an excellent overview: A Vedaschi, 'Globalization of Human Rights and Mutual Influence between Courts: The Innovative Reverse Path of the Right to the Truth' in Shimon Shetreet (ed), The Culture of Judicial Independence, Rule of Law, and World Peace (Brill-Nijhoff 2014). DOI: 10.1163/9789004257818. ${ }^{63}$ All findings made subsequently by the Court El-Masri, supra $\mathrm{n} 4$.

${ }^{64}$ Kurt, supra $\mathrm{n} 18$.
} 


\section{Approach}

\subsection{Origins}

The Court's SoP is its own to decide. In addition it is not bound by any strict rules of evidence, but can admit what evidence it chooses. ${ }^{65}$ In Ireland $v$ United Kingdom the Court indicated for the first time that BRD is the SoP it requires. ${ }^{66}$ Although the Court did not explain its reasons for taking up this standard, - which it did in spite of challenge from Ireland, - it did so following the same approach taken by the Commission in the 'Greek case' ${ }^{67}$ In the Greek case, the Commission also clarified its interpretation of 'reasonable doubt' as a 'doubt for which reasons can be given drawn from the facts presented. ${ }^{68}$ The Court has never directly used this, though in Ireland it added that 'proof may follow from the coexistence of sufficiently strong, clear and concordant inferences or of similar unrebutted presumptions of fact. ${ }^{, 69}$ Furthermore, '[i]n this context, the conduct of the Parties when evidence is being obtained has to be taken into account. ${ }^{70}$

The Court recognizes that sometimes it is not possible for an applicant to bring very concrete evidence of the alleged violation to the Court. This is usually a practical problem, such as illustrated above, symptomatic of the power dynamic operating in two dimensions: between applicant(s) and a respondent state on one hand, and between the state and the Court on the other. It is also a common indicator of a less than cooperative state in the judicial

\footnotetext{
${ }^{65}$ Ireland, supra $\mathrm{n} 2$, para 209.

${ }^{66}$ Ibid. para 161.

${ }^{67}$ Denmark, Norway, Sweden and the Netherlands v Greece Appl nos 3321/67, 3322/67, 3323/67 and 3344/67 Commission Decision (5 November 1969).

${ }^{68}$ Ibid.

${ }^{69}$ Ireland, supra $\mathrm{n} 2$, para 161.

${ }^{70}$ Ibid.
} 
process. The two substantive areas in which evidence creates a particular practical difficulty for applicants are right to life and liberty claims concerning disappearances, and cases addressing possible violations of the prohibition of torture and other ill-treatment, more often torture. Usually, in both types of case, the respondent state has, or ought and is therefore presumed to have, information which would shed further light on the issue, yet supplies only vague information to the Court or none at all. In such circumstances the applicant finds themselves at a significant disadvantage proving their case. This had catastrophic implications early on, as in the disappearance case Kurt $v$ Turkey. The Court was unable (or unwilling) to find violations under Articles 2 and 3 because the applicant was unable to prove BRD that her son had been killed and/or tortured by the state. This was against a background when the UN Working Group on Enforced Disappearances had even flagged Turkey as having the most disappearance cases in the world at the time. ${ }^{71}$

Disappearance cases, and Kurt in particular, can be seen as the catalyst for a change in the Court's approach. In this type of case, the state's silence, denying allegations and not being forthcoming with facts is part and parcel of the phenomenon. Denial is 'a definitional element of enforced disappearance', ${ }^{72}$ and invariably the state will not cooperate in court proceedings. It may even actively try to undermine them, on which basis Keller and Heri label such uncooperative states 'subversive objectors. ${ }^{73}$ The Court's shift towards a willingness, in appropriate circumstances, to make inferences favourable to the applicant and reversing the BoP came initially through the case law. This was later formalized in part in the 2004 revision to the Rules of Court so that although the Court has no real power to compel the respondent state to disclose information, 'failure to participate effectively' in proceedings

\footnotetext{
${ }^{71}$ Sethi, supra n 17; UNCHR, 'Report of the Working Group on Enforced Disappearances' E/CN.4/1995/36 para 402.

${ }^{72}$ Keller and Heri, supra n 19 at 749.

${ }^{73}$ Ibid. at $737-8$.
} 
enables it to 'draw such inferences as it deems appropriate. ${ }^{74}$ The rebuttable nature of those inferences, - that is, the reversed BoP,- is implied only. But since the full approach began with the case law, it is this we turn to first.

\subsection{Change in approach: the Case Law}

The decision in Kurt did not appear at the time to serve justice, and was deeply unsatisfactory. ${ }^{75}$ Two cases which followed shortly after marked a sea change in the Court's approach to disappearances. On 8 July 1999, in Çakici v Turkey, the Grand Chamber handed down a judgment that by the detention and disappearance of Ahmet Çakici, Turkey had violated Articles, 2, 3 and 5 ECHR. Ahmet Çakici had disappeared after being taken into custody by the security services. Though the Turkish government sought to rely on Kurt to defeat the claim, the Court instead distinguished the cases explaining 'in the Kurt case, although the applicant's son had been taken into detention, no other elements of evidence existed as regarded his treatment or fate subsequent to that. ${ }^{76}$

There were more details in Çakici, including from witnesses with whom he had been incarcerated, about what had happened to Çakici during his detention: he was beaten, had broken a rib, his head was split open, and he was taken for interrogation a number of times, where he received electric shocks and was beaten further. ${ }^{77}$ Turkey disputed the facts and so the Commission undertook its own an investigation. Faced with a government that was, to borrow Keller and Heri's term, most assuredly a 'subversive objector', - including that one witness called on by the Commission, Hikmet Aksoy, himself disappeared before giving evidence, - the Commission found it apt to make inferences. In particular, the Commission made 'very strong inferences' from the authorities' claim they had found the victim's identity

\footnotetext{
${ }^{74}$ Rules of Court; $44 \mathrm{C} \S 1$.

${ }^{75}$ Supra n 17.

${ }^{76}$ Çakıcı v Turkey [GC] Appl no 23657/94 (8 July 1999) para 85.

${ }^{77}$ Ibid. paras 15-16.
} 
card on the body of a dead terrorist. ${ }^{78}$ They also took into account documentation that was incomplete and/or misleading and witness statements made on the state's behalf that similarly did not add up. As the government could not account for what had happened to Çakici, the Court took the same line as the Commission, holding that this created a presumption Çakici had died. Finding Turkey liable for his death, the Court was clear there was 'sufficient circumstantial evidence, based on concrete elements, on which [this] may be concluded beyond reasonable doubt'. ${ }^{79}$

It is questionable how far this case on its own represented a shift in the Court's approach. Through Ireland, the Court had already long since declared inferences (a significant plural) were capable of discharging the BRD standard, where 'strong, clear and concordant'. The variance between Kurt and Çakici, certainly as the Court distinguished the cases, stays true to that original Ireland formulation, because it requires inferences which are not only strong, but also coexisting. Whether this does truly represent proof BRD is a separate question, these facts recalling Erdal's criticism that presuming death where death is not fully known or established does not constitute BRD ${ }^{80}$ Nevertheless, on the Court's construction of BRD, it does.

The Court also found the 'required standard of proof, i.e. beyond reasonable doubt, that Çakici was tortured during his detention' was supported by the evidence ${ }^{81}$ particularly a detailed witness statement from a man who had shared a cell with the victim, and who had been subjected to similar torture. The Court did not refer directly to its SoP when finding Çakici's 'unacknowledged' detention violated Article 5 ECHR, but accepted the Commission's finding, - based on witness evidence, that there were no accurate or reliable

\footnotetext{
${ }^{78}$ Ibid. para 85.

${ }^{79}$ Ibid. para 92.

${ }^{80}$ Erdal, supra $\mathrm{n} 3$ at 68 , also supra $\mathrm{n} 24$.

${ }^{81}$ Çakıcl, supra n 76, para 92.
} 
records about people taken into custody by the Gendarmes, and that there had not been any meaningful inquiry into what had happened, - that he had been detained in this way.

Çakici was followed shortly after by another disappearance case, Timurtas $v$ Turkey, which was handled in a similar way. Timurtas was similarly distinguished from Kurt, ${ }^{82}$ though not without criticism and it is the difference (and similarity) among the three cases which really emphasizes a shift in the Court's thinking at this time. In his partly dissenting opinion, Judge Gölcüklü was unequivocal, - as the Commission had similarly pointed out, Timurtas was 'indistinguishable from the Kurt case (in which, as in this case, it was not established beyond all reasonable doubt that the applicant's son, Üzeyir Kurt, died in detention) and has nothing in common with Çakıcl'.83

On the facts it is impossible to disagree with the first point. If anything, Timurtas' detention by the authorities was less evidenced than was Kurt's. Nevertheless the Court, possibly empowered by Çakici which was a Grand Chamber decision, and almost certainly alive to the need for a change to serve justice, followed (arguably extended) this later approach, holding that Articles 2, 3, 5 and 13 had all been violated.

Together Çakici and Timurtas marked a 'positive shift' in the Court's approach, which 'tacitly acknowledged the wider socio-political context of the 1990s within which unacknowledged detentions and enforced disappearances had posed serious threats to human life. ${ }^{84}$ The correctness or otherwise of departing from Kurt is a historical point and barely important now for at least four reasons: the ECHR is a 'living instrument', of which dynamism on the part of the Court to deliver justice in line with the ECHR's purpose is

\footnotetext{
${ }^{82}$ Timurtas v Turkey Appl 23531/94 Merits and Just Satisfaction (13 June 2000). See also O Bakircioglu and B Dickson, 'The European Convention in conflicted societies: the experience of Northern Ireland and Turkey' (2017) 66 International \& Comparative Law Quarterly 263. DOI: 10.1017/S0020589317000033.

${ }^{83}$ Ibid. Partly Dissenting Opinion of Judge Gölcüklü, para 5.

${ }^{84}$ Bakircioglu and Dickson, supra $\mathrm{n} 82$ at 288.
} 
surely a key aspect; the Court is not required to follow precedent, including its own; the Court can set its own rules of evidence (including the SoP); and this approach is now very firmly entrenched in the Court's jurisprudence ever since. But there is more in this than a change in approach out of sensitivity to the 'socio-political context' and a practical need to deliver justice. The Court was then, and is still now keen to emphasize the circumstantial evidence was sufficient to meet its BRD standard, an illustration of which is even in recent Grand Chamber decisions that include the wording of Ireland verbatim. ${ }^{85}$ The present task is still elaborating and making sense of the Court's own conception of BRD, its origins and in particular, how much doubt it allows for. Yet the third tension question keeps returning: why is the Court, which can set its own evidential standard, so faithful to BRD?

\subsection{Rules of Court: Rule 44C\$1}

The problem of subversive objector states is quite evident. In the 1990s the Court was grappling with its own SoP when facing a lack of concrete evidence, as well as outright denial, in disappearance cases brought against Turkey. In December 2004 Rule 44C§1 was added to the Rules of Court, confirming and formalising the Court's reliance on circumstantial evidence when a party in the case is not cooperating fully in the process. The Rule states:

Where a party fails to adduce evidence or provide information requested by the Court or to divulge relevant information of its own motion or otherwise fails to participate effectively in the proceedings, the Court may draw such inferences as it deems appropriate.

\footnotetext{
${ }^{85}$ Most recently Merabishvili v Georgia [GC] Appl no 72508/13 Merits and Just Satisfaction (28 November 2017) paras 313-315, extracts of which are included in Navalnyy v Russia [GC] Appl no 29580/12 Merits and Just Satisfaction (15 November 2018). Also Khlaifia and Others v. Italy [GC] Appl no 16483/12 Merits and Just Satisfaction (15 December 2016), para 168.
} 
This is undoubtedly useful to the Court, since it puts beyond question its use of inference in cases of this of kind, though it is also noted above that this only captures part of the Court's approach. If the SoP is still to be met with the highest possible certainty, an obvious corollary of inference is the possibility of its rebuttal. The intimate connection between SoP and BoP in this context is thus very clear, rebuttal representing the reversed BoP. The Court's practice reflects this and its approach breaks down into three main elements. First the Court makes a statement that its SoP is BRD. Second, it recognizes the respondent government is in the stronger position and asserts its option to make inferences. Third, when the government fails to supply information, the Court considers the merits of the case based on the facts submitted by the applicant (ie. rebuttable inference), with or without corroboration from a third source. Rule $44 \mathrm{C} \S 1$ however, does not mention a reversed BoP. This, together with the Court's inconsistent direct use of the Rule in its case law, where it more often adopts the approach but cites case law and not the Rule, raises questions as to the Rule's continued relevance.

Although it has been operative for fifteen years, the Court has applied the Rule expressly in only a small number of cases. ${ }^{86}$ This on its own is no great surprise: the Court not being a court of first instance, the facts in the majority of cases have been settled long before they reach Strasbourg. Accordingly, relevant cases are drawn from only a relatively small cluster where facts are disputed, within which the Court must also observe, and have need to address, a situation where one of the parties in the dispute is not fully participating. The type of issues covered when the Court has invoked the Rule confirms that it is mostly needed where the stakes are very high indeed: generally a matter of life, and/or physical safety. However, there are significantly more cases in which lack of state cooperation has caused the Court to make inferences and reverse the BoP without citing the Rule, than when it has.

\footnotetext{
${ }^{86}$ At the time of writing, (February 2019), the Court has directly invoked the rule on 24 occasions. In a handful of further cases the Rule has been referred to, but not applied.
} 
Accepted, BoP is not included in the Rule, but the reversed BoP comes into operation only when inference has been made, hence the Rule is applicable in every one of these cases. Yet in 2018 and 2017, the Court reversed the BoP, respectively, in thirteen and fourteen cases, while directly invoking the Rule in only in two. ${ }^{87}$ In 2016, although the Court reversed the BoP in twenty-seven cases, not once did it refer to Rule 44C $\$ 1$. Indeed, since 2010, Rule $44 \mathrm{C} \S 1$ has been invoked in only seventeen cases, but the BoP reversed in many more.

Why does this matter? Firstly, it is helpful and not unreasonable to expect a court, not least an international court of the Court's standing, to be consistent. Whilst its approach is consistent, the Court's direct reference to Rule $44 \mathrm{C} \S 1$ is not, without there being any obvious objective difference between cases where the Rule is or is not cited. Lack of consistency may have implications for the strength, efficiency and legitimacy of decisions, and even if that risk is overstated, a consistent approach would nevertheless reinforce the credibility of the Court's approach. Secondly, if reliance on the approach as set out in abundant case law is enough, there is doubt over the added value of retaining the Rule: a doubt that is only emphasised by its incompleteness. Arguably the Rule legitimates the Court's approach, but the Court has developed other principles through its case law, such as proportionality and margin of appreciation, without the need to codify them in its Rules of Procedure. Moreover, since the BoP is not accommodated in the Rule, the case law will always need to be cited in any event.

This appears to yield three options for the Court, the first of which is to do nothing and continue being inconsistent. For the reasons above, this is the least desirable choice. Secondly, the Court could get rid of the Rule altogether, eliminating at the same time the available choice of invoking it or not. Or thirdly, the Court could choose to update Rule $44 \mathrm{C} \S 1$ to fully reflect the approach set out in its case law, and commit to consistently

\footnotetext{
${ }^{87}$ Merabichvili and Navalnyy, supra $\mathrm{n} 85$.
} 
referring to that updated Rule on every occasion it is applied. Both these latter two options would improve consistency, but the third is preferable. Rule $44 \mathrm{C} \S 1$ provides the Court with a certain level of insurance from criticism, even if it is not directly invoked by the Court, as it sets out unambiguously its willingness to make inference and thereby reaffirms legitimacy. Revoking the Rule would remove that security, and could conceivably even weaken the Court's position in this regard. Updating the Rule instead would keep in place that security and provide two significant opportunities. Firstly, as it updates the Rule, the Court could take stock of its approach from across the case law and clarify it fully. Secondly, if the Court were in future to refer to the Rule consistently, its use would be a clear warning signal, enabling the Council of Europe mechanisms and others more easily to identify patterns across states in the relevant case law and from there to look at strategies to address specific issues.

At present, the Court's citation of Rule $44 \mathrm{C} \S 1$ draws particular attention to three states: Turkey, Russia and Bulgaria. The full range cases in which the Court has reversed the BoP in recent years however, indicates a pattern of behaviour also from Azerbaijan, Ukraine and Lithuania. These states would be missed in looking purely to direct use of the Rule.

\subsection{Observations}

In summary of this Section a series of observations can be made. Firstly, when the Court makes inferences this has significant implications for both the SoP and the BoP. Rule 44C§1 formalizes the Court's use of inference first introduced in Ireland as capable of satisfying the BRD standard. Inference became a more vital tool to the Court when it was faced in the 1990s with an unhealthy power differential between the State and applicants in disappearance cases in which Turkey attempted to subvert process. The Court's general approach in such circumstances has evolved so that the Court is willing to make inferences of fact. Since, as fairness requires it, these inferences are rebuttable, the result is a shift in the BoP onto the 
respondent state, i.e. the onus then falls on the state to disprove the alleged facts. Rule $44 \mathrm{C} \S 1$ is an enabler of sorts, removing any argument in a given case that the Court's use of inference is inappropriate, it essentially reinforces the legitimacy of this approach.

However, the Court does not always refer to the Rule expressly in every case, the failure to address which may be something of a lost opportunity for two reasons: to reinforce the consistency, strength and legitimacy of relevant decisions; and to identify patterns across states and relevant case law. While it is possible only to speculate on the reasons for this sometime omission, they may include that the Court's general approach is not represented in its entirety in the Rule itself. The reversed BoP, though the obvious corollary of rebuttable inference, is not set down.

Most critical to this work is that the Court has an established and recognisable approach to subversive states, and that on every occasion the approach is deployed it insists (verbatim from Ireland) that BRD is its SoP. In spite of this, there is still occasion for doubt in these cases for two reasons. Firstly, conclusive evidence is simply not always available to the Court: the practical problem the Court's approach attempts to overcome. Secondly, doubt is built into the structure of that approach. The Court can make inferences, but the credibility and relative weight of evidence relied on to arrive at these inferences depends on the specifics of the case. It follows that the strength of the inferences themselves may vary from case to case. This is subject to circumstance and not in the Court's power to do anything about. Where the state is not cooperating but has or, because of its privileged position, should have access to more information than the applicant, the approach brings greater parity between the parties. Reversing the BoP is designed to force the respondent state's hand, which must then disprove the Court's inferences. It therefore goes some way to addressing the problem but it will not necessarily yield definitive proof of the applicant's version of events. 
It is thus tempting to echo Erdal's sentiments that the Court's declared SoP is a fiction and not BRD at all, irrespective of the Court's claim to the contrary. However, the Court's conviction is both firm and consistent, and it is this article's purpose to clarify the Court's interpretation and application of its SoP. Accordingly, it serves better to accept the Court's particular conception of BRD, by its structure, accommodates some degree of uncertainty of facts. The critical question is then: how much doubt does the Court's conception of BRD allow for? Or, framed by its opposite, how certain is the Court of facts when it finds BRD, a violation? This, through examination of the case law, is the question we turn to now.

\section{$7 \quad$ General Approach in the Case Law: How Certain?}

The Grand Chamber in Nachova v Bulgaria set out some key points in its statement of general principles, repeated in subsequent cases. ${ }^{88}$ Opening with a firm insistence its SoP is BRD, it adds three points. Firstly, the purpose of the proceedings are different from those in domestic law. The Court's task of ensuring states are complying with the Convention 'conditions its approach to the issues of evidence and proof. ${ }^{89}$ Secondly, the Court is not constrained by procedural rules, so can admit and assess evidence as it deems fit. Through a 'free evaluation of all evidence', including inferences drawn from the facts it reaches its conclusions. Proof it adds with the Ireland qualifier, can follow from the "coexistence of sufficiently strong, clear and concordant inferences or of similar unrebutted presumptions of fact.' Finally, in a nod to the persuasive weight of evidence:

the level of persuasion necessary for reaching a particular conclusion and, in this connection, the distribution of the burden of proof are intrinsically linked to the

\footnotetext{
${ }^{88}$ Nachova, supra n 4, para 147; also Creangă and El Masri, supra n 4; Ermakov v Russia Appl no 43165/10 Merits and just Satisfaction (7 November 2013); Al Nashiri (n 25); Merabichvil and Navalnyy, supra $\mathrm{n} 85$. ${ }^{89}$ Ibid.
} 
specificity of the facts, the nature of the allegation made and the Convention right at stake. ${ }^{90}$

The statement confirms the Court's own particular conception of BRD in the abstract at least. It also underscores that the Court works on a case by case basis, its approach led by the facts before it, and that some level of uncertainty may still be underlying. Redistribution of the $\mathrm{BoP}$ is a mechanism to address that but nevertheless, the requisite 'level of persuasion' to satisfy the Court's conception may be variable. It is therefore helpful to recall the Commission's view in the Greek case that 'reasonable doubt' is 'a doubt for which reasons can be given drawn from the facts presented.' ${ }^{91}$ It is not 'a doubt based on a merely theoretical possibility or raised in order to avoid a disagreeable conclusion' ${ }^{92}$ With this measure in mind, let us turn to the case law in which, as will be demonstrated, the Court is seen consistently to strive for the highest degree of certainty it can attain in a given case.

There are two central challenges to this proposition. The first is through a series of Bulgaria cases decided between 2005-8 which showed an increasingly loose approach to circumstantial evidence. The second is, at first glance, a more recent development by which the Court has directly referred to and relied on the constructive knowledge of the state in question.

The Bulgarian cases concerned allegations of inhuman and degrading conditions in detention facilities run by the Bulgarian Investigation Services. Since Bulgaria is a State Party to the European Convention for the Prevention of Torture, it receives regular visits from the European Committee for the Prevention of Torture (CPT). The nature of the applications before the Court meant the CPT's findings were relevant and the Court could

\footnotetext{
90 Ibid.

${ }^{91}$ Supra n 67.

92 Ibid.
} 
look at its published Reports on visits to Bulgaria as additional evidence. ${ }^{93}$ These decisions highlight the Court's willingness to decide cases based on evidence that was increasingly far removed from the immediate allegations before the Court. Specifically, it was prepared to base its decisions on the CPT's visit reports even when the Committee had not visited the same facilities as those concerned in the respective applications to the Court. ${ }^{94}$ In other cases the use of CPT reports was directly challenged, but not defeated, because of a gap of up to four years between the visit and the inhuman and degrading conditions alleged. ${ }^{95}$ Inexplicable as it is noteworthy, in two Bulgaria cases during this period in which the state was more cooperative, the Court did not name the BRD standard at all. ${ }^{96}$

In any event Navushtanov $v$ Bulgaria decided in 2007, is a good example in which the Court did at least concede the limits of CPT Reports as evidence while nevertheless according them significant weight:

While not directly relevant, because the Velingrad Investigation detention facility was never itself visited and the reports cover somewhat different periods, the Court considers that the general observations of the $\mathrm{CPT}$ in respect of the conditions of detention in all Investigation Service detention facilities during its visits, in so far as relevant, may also inform it in its decision. ${ }^{97}$

On this, three points are notable. Firstly, the application concerned two separate detention facilities, and whilst Bulgaria made unchallenged submissions about the second, they did not

\footnotetext{
${ }^{93}$ On the relationship between the Court and the CPT, see C Bicknell, M Evans and R Morgan, Preventing Torture in Europe (Council of Europe 2018).

${ }^{94}$ I.I. v Bulgaria Appl no 44082/98 Merits and Just Satisfaction (9 June 2005); Staykov v Bulgaria Appl no 49438/99 Merits and Just Satisfaction (12 October 2006); Malechkov v Bulgaria Appl no 57830/00 Merits and Just Satisfaction (28 June 2007).

${ }^{95}$ Navushtanov v Bulgaria Appl no 57847/00 Merits and Just Satisfaction (24 May 2007); Kostadinov v Bulgaria Appl no 55712/00 Merits and Just Satisfaction (7 February 2008); Gavazov v Bulgaria Appl no 54659/00 Merits and Just Satisfaction (6 March 2008).

${ }^{96}$ I.I. supra n 94; Kehayov v Bulgaria Appl no 41035/98 Merits and Just Satisfaction (18 January 2005).

${ }^{97}$ Supra n 95, para 118. Emphasis added.
} 
comment on those in Velingrad. Accordingly, it was in respect of Velingrad only that the Court considered the merits based 'solely' on the applicant's version of facts. ${ }^{98}$ Secondly, as Sabeva v Bulgaria also confirms, ${ }^{99}$ the Court was willing to make inferences and rely on the CPT's findings that were not fully relevant because the CPT included comments in its reports about Investigation Service detention facilities generally. According to the CPT, general conditions encountered in like facilities four years before the allegations 'almost without exception ... could fairly be described as inhuman and degrading', ${ }^{100}$ whilst general comments from the visit at roughly the same time as the facts under consideration confirmed almost nothing had changed and in some cases conditions had deteriorated. ${ }^{101}$ Conversely, the lack of a general comment on conditions in Bulgarian psychiatric facilities, had in fact meant the Court declined to make similar inferences in Sabeva ${ }^{102}$ Finally, when all the facts were considered, the Court found there had not been a violation of Article 3 ECHR as the requisite threshold of severity for inhuman and degrading treatment had not been met. Therefore, although Navushtanov opened up the possibility that inference based on relatively weak circumstantial evidence could inform a decision, in the case itself, it did not. With no comparable case in which a violation has been found, it is therefore impossible to gauge the likelihood of that occurring in the future, and it is possible that in reality it never would.

The remaining relevant case law makes the Court's thoroughness and the very high levels of certainty of facts it requires abundantly clear and it is relevant to consider this first before turning to constructive knowledge. El-Masri v Former Yugoslav Republic of Macedonia (FYROM) is one case which leaves almost no room for doubt, although the Court still nevertheless reversed the BoP. ${ }^{103}$ The United States litigation on the same matter was

\footnotetext{
98 Ibid.

${ }^{99}$ Sabeva v Bulgaria Appl no 44290/07 Merits and Just Satisfaction (10 June 2010).

${ }^{100}$ Ibid. para 34.

${ }^{101}$ Ibid. paras 37-38.

102 Ibid. para 41.

${ }^{103}$ El-Masri, supra n 4.
} 
discussed above, though here the Court considered the role FYROM played in El-Masri's extraordinary rendition. There was a significant amount of high quality evidence available to it, and the Court was persuaded particularly by the applicant's detailed, specific and consistent accounts. These found support from 'indirect evidence', including flight logs. The applicant's case was also supported by both the Marty Report ${ }^{104}$ and the Fava Report, ${ }^{105}$ the latter of which referred to Khaled El-Masri by name. There was even a written statement confirming El-Masri's incommunicado detention from H.K. who had been FYROM's Minster of the Interior at the relevant time. By triangulating all of the evidence, the Court's 'assumptions' left little room for doubt, though in the process they still regarded this as 'prima facie evidence' in the applicant's favour, and reversed the BoP.

El-Masri may have been unusual for the very high level of certainty the Court was able to find in the facts. As already noted, one crucial impediment to full certainty is available evidence. The Court's rigour when faced with extremely challenging evidential barriers is especially marked in the cases of Al Nashiri v Poland, ${ }^{106}$ Husayn (Abu Zubaydah) $v$ Poland, ${ }^{107}$ and Al Nashiri v Romania. ${ }^{108}$ The first two of these were decided together, and there is obvious overlap in the Al Nashiri judgment against Romania. In essence, Al Nashiri and Abu Zubaydah were both subjected to extraordinary rendition by the United States during which they were transferred to secret and unacknowledged detention facilities known as 'black sites' located in Poland and run by the CIA. There, at the hands of the CIA, they were tortured. ${ }^{109}$ In Romania contrastingly, the Court did not have evidence to find the CIA had tortured Al Nashiri. It did find however, 'beyond reasonable doubt' that he had been held

\footnotetext{
${ }^{104}$ Alleged secret detentions and unlawful inter-State transfers of detainees involving Council of Europe member States, Doc. 10957, 12 June 2006 ('the 2006 Marty Report').

${ }^{105}$ European Parliament: the Fava Inquiry, CIA Activities in Europe:

$<$ http:/www.europarl.europa.eu/sides/getDoc.do?type=IM-

PRESS\&reference $=20070209$ IPR02947\&language $=\mathrm{EN}>$ accessed 3 July 2019.

106 Supra n 25.

107 Ibid.

${ }^{108}$ Al Nashiri v Romania Appl no 33234/12 Merits and Just Satisfaction (31 May 2018).

${ }^{109}$ Al Nashiri v Poland (n 25), para 516; Husayn (Abu Zubaydah), supra n 25, para 511.
} 
under a particular type of regime ('standard conditions of confinement') and that cumulatively his conditions and treatment amounted to inhuman treatment. ${ }^{110}$

It is not necessary for present purposes to dissect these cases in full, so for reasons of overlap Al Nashiri v Poland is taken as illustrative. The evidential barriers included: the applicants had not had contact and had restrictions placed on communication with the outside world; ${ }^{111}$ one of the deliberate intentions of rendition is to disorient and isolate the victim; ${ }^{12}$ the secrecy surrounding rendition; ${ }^{113}$ claims of national security compounding this $;{ }^{114}$ and (not an issue in respect of the Romania case), Poland's failure to submit to the Court relevant information to which it had access. ${ }^{115}$ This last the Court found to be a hindrance of its work under Article 38 ECHR, entitling it to draw 'inferences' ${ }^{116}$ '[I]n consequence' of all of these barriers, the Court was pragmatic and clear:

establishment of the facts is to a great extent based on circumstantial evidence, including a large amount of evidence obtained through the international inquiries, considerably redacted documents released by the CIA, other public sources and evidence from the experts and the witness. ${ }^{117}$

The volume of materials consulted and the highly detailed and considered handling of them stands as testament to the Court's thoroughness. The facts established are themselves very detailed, including flight numbers and dates. Inferences were inevitably made and the BoP reversed. Following, it was established BRD, that: on 5 December 2002 Al Nashiri and Abu Zubaydah arrived in Szymany on CIA rendition flight N63MU; from which date they were

\footnotetext{
110 Al Nashiri v. Romania, supra n 108, paras 670-675.

111 Paras. 399-400.

112 Al Nashiri v Poland supra n 25, para 398.

113 Ibid. para 400.

114 Ibid. paras 365-366.

115 Ibid. paras 360, 375 .

116 Ibid. para 375.

117 Ibid. para 400.
} 
detained in the CIA detention facility codenamed 'Quartz' in Stare Kiejkuty, Poland; where they were subjected to torture, and; from which the CIA transferred them, leaving Poland, on 6 June 2003 on rendition aircraft N379P. ${ }^{118}$ Findings so specific, determined by such careful sifting of high volumes of materials in evidence are not suggestive of very much, if any, doubt at all.

The case was brought however, to establish Poland's role and culpability, a key feature of which pertains to its knowledge at the relevant time of what was occurring on its territory. Although the Court found Poland must have known about flights landing on its territory, the Court accepted that the authorities might not have known exactly the treatment to which the applicants were subjected in the 'black sites'. That is, the Court accepted it was not possible to conclusively establish Poland's direct knowledge of the ill-treatment, following which the matter of what they 'ought to have known' became key. Hence, a fascinating and arguably novel feature of the Poland decisions is the appearance of constructive knowledge, ${ }^{119}$ and this had to be measured by what they should have known at the time (not with hindsight). ${ }^{120}$ Incidentally, at the relevant time in the case against Romania, - to which Al Nashiri was transferred after being held in Poland,- there was sufficient information in the public domain to presume the authorities knew a serious risk of illtreatment existed. ${ }^{121}$ Considering Poland, the Court articulated that its SoP is BRD with all the caveats and explanations already seen. ${ }^{122}$ It nevertheless, and not unreasonably, found constructive knowledge.

\footnotetext{
118 Ibid. para 417.

${ }^{119}$ For a considered discussion see NHB Jorgensen, 'Complicity in Torture in a Time of Terror: Interpreting the European Court of Human Rights Extraordinary Rendition Cases' (2017) 16 Chinese Journal of International Law 11-40.

${ }^{120}$ Al Nashiri v Poland, supra n 25, para 440; Husayn (Abu Zubaydah), supra n 25, para 442.

${ }^{121}$ Al Nashiri v Romania, supra n 108, para 588.

122 Al Nashiri v Poland, supra n 25, para 394.
} 
[G]iven that knowledge and the emerging widespread public information about illtreatment and abuse of detained terrorist suspects in the custody of the US authorities, [Poland] ought to have known that, by enabling the CIA to detain such persons on its territory, it exposed them to a serious risk of treatment contrary to the Convention. ${ }^{123}$

Constructive knowledge acts as a substitute for actual knowledge, and in this way, we can regard its use in the Poland cases as inference of a very particular kind. In truth, presumptions are already frequently made by the Court, for example when a detained person suffers injury, it is presumed the state knows what happened. Although not expressed in the same terms as above, in both cases there is a rebuttable presumption made specifically to the context, and which necessarily includes knowledge. Hence rather than introducing a new approach, $A l$ Nashiri $v$ Poland merely adapts the Court's pre-existing one to the circumstances, including explicit reference to knowledge.

There is abundant evidence elsewhere in the case law of the Court triangulating evidence, and considering possibilities other than the applicant's submission to build the most credible factual account it can. To give an example, in Alimov v Turkey, and Yarashonen $v$ Turkey the Court took on board the CPT's findings about overcrowding and conditions at Kumkapi Removal Centre for migrants, ${ }^{124}$ considering that with three years having elapsed between the Committee's visit and the allegations, improvements may have been made. But it then looked at reports from members of the Grand National Assembly of Turkey who had visited, and the UN Special Rapporteur on the Human Rights of Migrants, which confirmed the problem remained.

\footnotetext{
${ }^{123}$ Ibid para 517, emphasis added.

${ }^{124}$ Alimov v Turkey Appl no 14344/13 Merits and Just Satisfaction (6 September 2016); Yarashonen v Turkey Appl no 72710/11 Merits and Just Satisfaction (24 June 2014).
} 
There may not always be even this amount of evidence and two additional points should be made. The Court will not accept all evidence that is presented to it, ${ }^{125}$ and there is not an automatic preference to the applicant. In Kasymakhunov v Russia for instance, the applicant's submissions were 'not particularly detailed' or supported, and when triangulated with other evidence the Court was not satisfied BRD of the claim. ${ }^{126}$ Furthermore, the Court is not always persuaded that the applicant's submissions warrant presumptions and a reversal of the BoP. ${ }^{127}$ Elsewhere the Court has found the government to have discharged the BoP successfully. ${ }^{128}$ Indeed, the Court's approach to discovering facts is overall quite balanced. In most relevant cases where a violation is found, the victim's account is detailed and consistent, a factor that carries a lot of persuasive weight with the Court. Chernetskiy $v$ Russia ${ }^{129}$ which application included detailed and consistent information of police illtreatment, is a case in example. It was relevant also that Chernetskiy's injuries were concordant with the medical evidence. The Court was not prepared to accept however, evidence on the medical file which said the applicant had been beaten by 'unknown persons' at a specified time before he had come into police custody. According to the Court this was 'not a conclusion made by the doctor on the basis of a medical expert examination, but information received from an unspecified source. ${ }^{130}$ The BoP was reversed and when neither the Russian authorities conducting the inquiry into the applicant's allegations, nor the Russian government, could give a 'convincing explanation' of how Chernetskiy acquired his injuries, inhuman and degrading treatment was established.

\footnotetext{
${ }^{125}$ Kyriacou Tsiakkourmas and Others v Turkey Appl no 13320/02 Merits and Just Satisfaction (2 June 2015), para 181.

${ }^{126}$ Kasymakhunov v Russia Appl no 29604/12 Merits and Just Satisfaction (14 November 2013).

${ }^{127}$ Malik Babayev v Azerbaijan Appl no 30500/11 Merits and Just Satisfaction (1 June 2017); Hentschel and Stark v Germany Appl no 47274/15 Merits and Just Satisfaction (9 November 2017).

${ }^{128}$ Idalov v Russia (No 2) Appl no 41858/08 Merits and Just Satisfaction (13 December 2016); Adam v Slovakia Appl no 68066/12 Merits and Just Satisfaction (26 July 2016).

${ }_{129}$ Chernetskiy v Russia Appl no 18339/04 Merits and Just Satisfaction (16 October 2014).

${ }^{130}$ Ibid. para 71.
} 
Chernetskiy is a useful illustration that maps well with disappearance cases in which there is similarly less than ideally conclusive, but nevertheless strong prima facie evidence of facts. The Court's selectivity of information on the medical file - distinguishing discovery of lesions on the body from reporting of reasons, - demonstrates its detailed consideration of all evidence. Moreover, where the evidence is not as strong as might be hoped, it is clear reversing the BoP plays a vindicating role for the Court, strengthening the accuracy of its findings. The state has opportunity to disprove an inference and when it cannot, violation even if not absolutely certain is nevertheless highly probable. Other cases in which the evidence grants a less than ideal level of certainty, still, through triangulation of evidence, show a consistently high level of probability in the facts. There is consistently a certainty in findings of rights violations that eliminates 'reasonable doubt' as defined in the Greek case.

\section{Conclusions}

It has been the purpose of this article to address the gap in current understanding of the Court's SoP, with the key aim of clarifying SoP as it is declared, interpreted and applied specifically by the Court. Unique from other analyses, the Court's SoP has necessarily been approached herein as a self-contained, stand-alone concept, specific and subject only to the Court's interpretation and application. At the beginning three specific tensions were identified which obscure full understanding of the Court's SoP, of which the first two relate directly to interpretation of terms. Through both it was shown the Court has its own conception respectively of SoP and BRD, a fact which reinforces the approach taken here of focussing exclusively on the Court's self-contained interpretation and application of its SoP. It was demonstrated that the first tension, by which the Court indicates it has only a single SoP in spite of considered academic commentary suggesting otherwise, is due to a difference in framing of the term. Whereas the Court conceives SoP only narrowly as a standard 
applying to proof of facts, it is elsewhere interpreted as having broader scope. The narrow construction informs the Court's position that it requires proof BRD to find a violation of a Convention right. BRD is itself subject to different interpretations, which forms the problem of the second tension. The Court has, through the history of BRD's use as its standard, encountered issues with access to evidence, including uncooperative states working against the judicial process. For this reason the Court had to adapt, and adopt its own nuanced approach whereby it is prepared to make inferences and reverse the BoP. This leaves room for some level of uncertainty for two reasons: the Court does not always have access to all relevant facts; and its approach of making inferences, by its structure and by definition, makes accommodation for some doubt. An inference is not full proof of fact. Nevertheless when the Court's approach is considered in full, and its application is assessed through the case law, it is abundantly clear the Court when it finds a violation in this way leaves very little, if any, room for real doubt.

To this an additional observation can be made. The Court in its overall statement of position in Ireland and since has not been speaking of proving individual fact(s) BRD, although in respect of certain facts within a judgment it often does this also. Rather the BRD proof is required to find whether there has been a violation of the relevant Convention right. ${ }^{131}$ The distinction is subtle but important, and the El-Masri and Al Nashiri cases reinforce it. Every single fact does not have to be proven, but the view formed overall from the available information must be proof BRD of a factual (as opposed to persuasive) point, that the violation occurred. It is demonstrated in this work that the Court achieves this, including by the additional guarantee of a reversed $\mathrm{BoP}$ which levels the ground between otherwise unequal parties. As assessment of the case law shows, the Court's approach in respect of uncooperative states is demonstrably clear, consistent and fairly applied.

${ }^{131}$ Ireland, supra $\mathrm{n} 2$ at para 161. 
Rule $44 \mathrm{C} \S 1$ on the other hand, is incomplete in its coverage of the Court's approach, and is unevenly and inconsistently invoked expressly by the Court. For this reason it is argued above that the Rule should be updated to comprehensively reflect the Court's approach as we see it in the case law, and that the Court should also then consistently refer to the Rule when it makes presumptions and reverses the BoP. Doing so would not only strengthen legitimacy, but also make it easier for the Court, other Council of Europe institutions and interested parties more broadly to identify patterns of uncooperative state behaviour and seek solutions to address them.

What remains uncertain is the reason for such a high evidential threshold as BRD. The tension itself was presented only briefly in Section 3. Though it may well be bound up in concerns over legitimacy, or quite possibly, albeit never declared as such, to serve a right to truth. The answer is not fully obvious. It does not seem from analysis of the second tension above however that the high threshold presents any particular impediment to the Court's fulfilment of its purpose. If it did we would expect more cases like Kurt, and almost certainly no violation findings in the rendition cases. In the final analysis, across all three tensions with their various pulls and crosswinds of challenge, the Court may be walking a tightrope but for the present, it is keeping its balance well. 